\title{
Detection of virulence factors in coagulase-negative Staphylococcus spp. strains isolated from Emmental cheese
}

\section{Detecção de fatores de virulência em cepas de Staphylococcus spp. coagulase negativos isoladas de queijo Emmental}

\author{
Adriana Loureiro do Nascimento' (1) (https://orcid.org/0000-0002-4184-8994) \\ Rosangela Sales Sousa ${ }^{2}$ (1) (https://orcid.org/0000-0001-8419-2545) \\ Aline Aparecida Rezende Rodrigues ${ }^{2}$ (1) (https://orcid.org/0000-0002-3067-4845) \\ Elaine Cristina de Mattos ${ }^{1}$ (1) (https://orcid.org/0000-0002-1052-8883) \\ Vilma dos Santos Menezes Gaiotto Daros' ${ }^{1}$ (1) (https://orcid.org/0000-0001-8359-0111) \\ Rute Dal Col' ${ }^{1}$ (1) (https://orcid.org/0000-0001-6633-7077) \\ Eliana Scarcelli Pinheiro 2 (1) (https://orcid.org/0000-0003-4142-6983) \\ Alessandra Figueiredo de Castro Nassar ${ }^{2 *}$ (1) (https://orcid.org/0000-0001-7490-9186)
}

\begin{abstract}
Food prepared with products derived from animals are involved in most cases of staphylococcal poisoning; therefore, the research of Staphylococcus spp. in Emmental cheese is more applicable. The objective of this study was to identify coagulasenegative Staphylococcus spp. (CNS) in cheese using biochemical and molecular techniques to detect the presence of nine genes responsible for the production of enterotoxins. From 180 samples analyzed, $204 \mathrm{CNS}$ strains were obtained and identified as being 46 (22.6\%) S. saprophyticus strains, 27 (13.2\%) S. hominis spp. hominis strains, 22 (10.8\%) S. sciuri strains, 21 (10.3\%) S. xylosus strains, 19 (9.3\%) S. epidermidis strains, 19 (9.3\%) S. haemolyticus strains, 17 (8.3\%) S. lentus strains, 17 (8.3\%) S. warneri strains, $11(5.4 \%)$ S. equorum strains and 5 (2.5\%) S. cohnni. Using the PCRm protocol, $14(6.9 \%)$ strains with the presence of the genes on the enterotoxin E (SEE) 11 (78.6\%), J (SEJ) 1 (7\%), C (SEC) $1(7 \%)$ and I (SEI) $1(7 \%)$ were detected. Based on the results, the type of package is not interfered of growth and isolated that Staphylococcus spp. in cheese. It was observed that bacteria capacity to produce coagulase cannot be understood as an indicative of enterotoxigenicity; therefore, the CNS should be considered as a target of importance in the epidemiology of staphylococcal intoxications. It can be concluded that CNS need to be included in bacterial foodborne disease research, since the genes responsible for the production of toxins were detected and none of the studied samples presented Staphylococcus spp. counting above the limits allowed by legislation.
\end{abstract}

RESUMO: Os alimentos preparados com produtos de origem animal são os mais envolvidos em casos de intoxicação alimentar estafilocócica; portanto a pesquisa do Staphylococcus spp. em queijos tipo Emmental é relevante. O objetivo foi isolar e identificar espécies de Staphylococcus coagulase negativas (CNS)de queijo Emmental acondicionado em vários tipos de embalagem, por meio de técnicas bacteriológicas e bioquímicas e detectar, por PCR, a presença de nove genes responsáveis pela produção de enterotoxinas. Das 180 amostras, foram isoladas 204 cepas de CNS, que foram identificadas por provas bioquímicas como: $46(22,6 \%)$ S. saprophyticus, 27 (13,2\%) S. hominis spp. hominis, $22(10,8 \%)$ S. sciuri, 21 (10,3\%) S. xylosus, 19 (9,3\%) S. epidermidis, 19 (9,3\%) S. haemolyticus, 17 $(8,3 \%)$ S. lentus, 17 (8,3\%) S. warneri, 11(5,4\%) S. equorum e 5 (2,5\%) S. cohnii. Na PCR multiplex, em 14 (6,9\%) isolados foi detectada a presença dos genes para enterotoxina $\mathrm{E}$ (SEE), em 11 (78,6\%) J (SEJ), em 1 (7\%) C (SEC) e em 1 (7\%) I (SEI). Com base nos resultados, o tipo de embalagem não interferiu na multiplicação dos Staphylococcus spp. isolados dos queijos. Neste estudo, verificouse que a capacidade para a produçáo de coagulase pela bactéria náo pode ser concebida como indicativa de enterotoxigenicidade, portanto devem-se considerar os CNS como objeto de importância na epidemiologia das intoxicaçóes estafilocócicas, fazendo-se necessária a atenção com relaçáo à pesquisa dos CNS nos alimentos, uma vez que foram detectados genes responsáveis pela produção de toxinas, e nenhuma das amostras apresentou contagem para Staphylococcus spp. acima do limite permitido pela legislação.

KEYWORDS: Staphylococcus; enterotoxin; food safety.

PALAVRAS-CHAVE: Staphylococcus, enterotoxina; segurança alimentar. 


\section{INTRODUCTION}

Consumption of cheese in Brazil in 2019 it was 1.12 million tons, considering that Brazil was classified as the fourth largest consumer of cheese, second only to the European Union, United States and Russia (SOUZA, 2020). According to a Brazilian cheese association (Associação Brasileira da Indústria de Queijos, ABIQ), in 2017, the production of cheese exceeded one million tons, an increase of $2 \%$ over 2016 , and the rate annual consumption is $5.5 \mathrm{~kg}$ per capita (kg/population/ year), with 2000 dairy industry that producing cheese in Brazil (REDAÇÃO DCI DIGITAL, 2018). Despite the use of different techniques to certify the quality and harmlessness of food, foodborne diseases (FBD) remain a health public problem (GERMANO et al., 1993). The Staphylococcus spp. are main agents of food intoxication outbreak, for being usually introduced in food through manipulators and asymptomatic carriers, since they are part of the transient microbiota of humans and animals (STAMFORD et al., 2006). Resolution RDC No. 12/2001 from the Brazilian National Agency of Health Surveillance established the limit of $10^{3}$ colony-forming unit per gram (CFU/g) for coagulase production by staphylococcal strains in fresh or matured cheeses collected from markets (BRAZIL, 2001). However, this resolution did not mention the coagulase-negative Staphylococcus spp. (CNS). The coagulase-positive species $S$. aureus is more related to outbreaks of food intoxication due to the characteristic of many strains to produce various types of staphylococcal enterotoxins (SE) (OMOE et al., 2005), but there are many previous studies in the literature (CARDOSO, 1999; SENA, 2000; CARMO et al., 2002; PIMENTEL et al., 2002) proving the toxicity of negative-coagulase species. Therefore, the presence of negative-coagulase species cannot be ignored, especially if they are going to be largely found in food, which indicates mainly poor hygiene practices of manipulators (JAY, 2000). The CNS were considered nonpathogenic bacteria until the discovery of responsible agents for nosocomial infections, although some species can cause infection in humans (KLOOS; BANNERMAN, 1994; CUNHA et al., 2002; CHANG et al., 2003).

The present work aims to identify species of CNS in Emmental cheese using biochemical and molecular techniques to identify the genes association with the production of enterotoxins, and thus evaluate the quality of the final product to costumers.

\section{MATERIAL AND METHODS}

\section{Cheese samples}

The cheese samples were produced in a dairy industry located in the city of Buritis (MG) according to Normative Instruction
No. 62/2003 (BRAZIL, 2003a). The dairy industry follows sanitary norms in relation to the quality of milk used for the production of cheese and meets effective good manufacturing practice (GMP) and sanitation standard operation procedures (SSOP) (BRAZIL, 1996).

Ten batches of Emmental cheese were produced, parted in three portions and packed with three types of package (resin, vacuum and modified atmosphere) each, within six different postproduction periods, at the dairy farm, totaling 180 samples. They were collected from day 0 of production until day 150 . The composition of the cheese packing was: the first one had a protection resin $(n=60)$; the second was vacuum-packed in plastic film $(n=60)$; and the third part of the cheese was packed only with plastic film and submitted to a modified atmosphere machine $(\mathrm{n}=60)$ that injected a gas mixture $\left(\mathrm{CO}_{2}\right.$, $\mathrm{O}_{2}$ and $\mathrm{N}_{2}$ ) into the package. The samples were refrigerated between 4 to $8^{\circ} \mathrm{C}$ and transported to the General Bacteriology Laboratory at the Biological Institute, São Paulo, Brazil, for microbiological analyses.

\section{Microbiological analyses}

An aliquot of $25 \pm 2 \mathrm{~g}$ from each cheese sample was prepared and $225 \mathrm{ml}$ of $0.1 \%$ peptone water were added in each different package. After that, the samples were vortexed for $60 \mathrm{~s}$ in the Stomacher 4000 Circulator (Seward) (10-1 dilution). Serial dilutions were performed, from the first dilution $\left(10^{-1}\right)$ until $10^{-4}$. Selective plating was done using $0.1 \mathrm{ml}$ of each dilution in Baird Parker Agar Difco, using Drigalski handle. Plates were incubated for $36 \pm 1{ }^{\circ} \mathrm{C}$ for $30-48 \mathrm{~h}$. The suggested colonies were identified Staphylococcus spp. using biochemic tests to confirm the genus (catalase and Gram-stained). Coagulase tube method, DNAse test, thermonuclease (TNAse) (BRAZIL, 2003b) and kits of identification API STAPH or VITEK 2 Compact system were used to determine the species according to the availability of the kit in the moment of the analyses.

\section{Statistical analysis}

The association of occurrence of Staphylococcus spp. and the package type (resin, vacuum or modified atmosphere) was calculated using the nonparametric chi-square test or the $\mathrm{G}$ test (SIEGEL; CASTELLAN JUNIOR, 2006) with significant level of $5 \%(p<0.05)$, with software BioEstat version 5.03.

\section{PCR for detection of genes (SE)}

The methods described by LØVSETH et al. (2004) were used to detect staphylococcal enterotoxin (SE) genes. Amplification of bacterial colonies for staphylococcal enterotoxin genes was performed adding $10 \mu \mathrm{L}$ of colony suspension to $40 \mu \mathrm{L}$ of mix of PCR reagents, [1.25 U Taq DNA polymerase, $200 \mu \mathrm{mol} \mathrm{L}^{-1}$ of each dNTP, buffer $\left(10 \mathrm{mmol} \mathrm{L}^{-1}\right.$ Tris- $\mathrm{HCl}$, 
$\left.\mathrm{pH} 8.0,50 \mathrm{mmol} \mathrm{L}^{-1} \mathrm{KCl}\right), 2 \mathrm{mmol} \mathrm{L}{ }^{-1} \mathrm{MgCl}_{2}$ ]. Two types of mix were prepared because of the large number of primers in the reaction. In the first step, named mix 1, the following primers were used in the concentration of 5 pmol $\mu \mathrm{L}^{-1}$ for each primer targeting the genes: SED, SEE, SEG, and SEI; and, in the second step, named mix 2 , with the following primers in the same concentration: SEA, SEB-SEC, SEC, SEH and SEJ. The two types of mix and the following conditions: initial denaturation of $95^{\circ} \mathrm{C}$ for 10 min followed by 30 cycles of denaturation at $95^{\circ} \mathrm{C}$ for $1 \mathrm{~min}$, hybridization at $68^{\circ} \mathrm{C}$ for $1 \mathrm{~min}$, and extension at $72^{\circ} \mathrm{C}$ for $1 \mathrm{~min}$, with a final extension of $72^{\circ} \mathrm{C}$ for $7 \mathrm{~min}$. A derivative strain of $S$. aureus (ATCC 13565) SEA gene producer was used as positive control, and sterile deionized water as a negative control.

The $10 \mu \mathrm{L}$ amplified products were homogenized with Blue Juice (Invitrogen) and then submitted to $1.5 \%$ agarose gel added TrisBorato EDTA (TBE) $0.5 \mathrm{X}\left(0.0045 \mathrm{~mol} \mathrm{~L}^{-1}\right.$ TRIS-Borato e $1 \mathrm{mmol} \mathrm{L}^{-1}$ de EDTA pH 8.0) buffer, with added 10000X red gel (Uniscience) at 1:125. Visualization of the bands was performed with an ultraviolet light transducer.

\section{RESULTS}

\section{Biochemical identification of Staphylococcus spp.}

From the 180 samples of Emmental cheese, none presented colony population above the allowed ( $<103 \mathrm{CFU} / \mathrm{mL}$ ) for Staphylococcus spp., but at least one isolate was obtained from each sample. The growth of 208 presumptive isolates of Staphylococcus genus was observed. The 208 isolated obtained were biochemically identified (Table 1) by VITECK 2 Compact and/or API STAPH. Four of the 208 isolates were confirmed as Aerococcus viridans, which do not belong to genus Staphylococcus, so these samples were removed from this study, totaling 204 isolates.

A total of 74 (35.6\%) strains of Staphylococcus spp. were isolated in the vacuum packages, $67(32.2 \%)$ in the resin packages and 67 (32.2\%) in the modified atmosphere package. After statistical analysis, no significant differences $(p=0.635)$ of growth between the types of packages were detected. Table 2 describes the genus and species identified in this study.

Table 1. Regular biochemical tests using API STAPH and/or VITECK 2 Compact for phenotypic identification of isolates.

\begin{tabular}{|c|c|c|c|c|c|c|c|c|c|c|}
\hline SPECIES & GLU & FRU & MNE & MAL & LAC & TER & MAN & XLT & MEL & NIT \\
\hline S. saprophyticus & + & + & - & + & + & + & + & - & - & $+/-$ \\
\hline S. hominis subsp. hominis & + & + & $+/-$ & + & $+/-$ & + & $+/-$ & - & - & + \\
\hline S. scuiri & + & + & + & + & $+/-$ & + & + & - & - & + \\
\hline S. xylosus & + & + & + & + & + & + & + & $+/-$ & - & + \\
\hline S. epidermidis & + & + & $+/-$ & + & + & - & - & - & - & + \\
\hline S. haemolyticus & + & + & - & + & + & + & $+/-$ & - & - & + \\
\hline S. lentus & + & + & + & + & + & + & + & - & + & + \\
\hline S. warneri & + & + & $+/-$ & + & - & + & $+/-$ & - & - & - \\
\hline S. equorum & + & + & + & + & + & - & + & $+/-$ & - & + \\
\hline S. cohnii & + & + & $+/-$ & + & - & + & + & $+/-$ & - & - \\
\hline SPECIES & PAL & VP & RAF & $X Y L$ & SAC & MDG & NAG & $\mathrm{ADH}$ & URE & \\
\hline S. saprophyticus & - & + & - & - & + & - & $+/-$ & $+/-$ & $+/-$ & \\
\hline S. hominis subsp. hominis & $+/-$ & $+/-$ & - & - & + & - & $+/-$ & $+/-$ & + & \\
\hline S. scuiri & $+/-$ & $+/-$ & - & - & + & - & $+/-$ & - & - & \\
\hline S. xylosus & + & $+/-$ & - & + & + & - & + & - & + & \\
\hline S. epidermidis & + & $+/-$ & - & - & + & - & - & $+/-$ & + & \\
\hline S. haemolyticus & - & $+/-$ & - & - & + & - & + & + & - & \\
\hline S. lentus & - & $+/-$ & + & + & + & $+/-$ & + & - & - & \\
\hline S. warneri & - & + & - & - & + & - & - & + & + & \\
\hline S. equorum & $+/-$ & $+/-$ & - & - & + & - & - & - & + & \\
\hline S. cohnii & $+/-$ & + & - & - & - & - & - & - & - & \\
\hline
\end{tabular}

GLU (D-glucose); FRU (D-fructose); MNE (D-mannose); MAL (D-maltose); LAC (D-lactose); TRE (D-trehalose); MAN (D-mannitol); XLT (xylitol), MEL (D-melibiose); NIT ( nitratereduction); PAL ( $\beta$-naphthylphosphate); VP (Voges-Proskauer); RAF (D-raffinose); XYL (D-xylose); SAC (D-sucrose); MDG (methylo-D-glucopyranoside); NAG (N-acetylglucosamine); ADH (L-arginine) and URE (urea). 
Table 2. Number of isolates identified by regular biochemical tests to API STAPH and/or VITECK Compact. Total isolates $=208$.

\begin{tabular}{|c|c|c|c|c|}
\hline $\begin{array}{c}\text { ISOLATES BY } \\
\text { PACKAGES TYPES }\end{array}$ & $\begin{array}{l}\text { No OF } \\
\text { BATCHES }\end{array}$ & ISOLATES & $\begin{array}{l}\text { TYPICAL COLONIES: } \\
\text { IDENTIFIED ISOLATES }\end{array}$ & $\begin{array}{l}\text { ATYPICAL COLONIES: } \\
\text { IDENTIFIED ISOLATES }\end{array}$ \\
\hline \multirow{10}{*}{$\begin{array}{c}\text { Vacuum }=74 \\
(35.6 \%)\end{array}$} & 01 & 08 & 06: S. lentus & 02: S. sciuri \\
\hline & 02 & 07 & 05: S. epidermidis & 02: Aerococcus viridans \\
\hline & 03 & 09 & 07: S. saprophyticus & 02: S. equorum \\
\hline & 04 & 08 & 05: S. saprophyticus & O3: S. hominis subsp. hominis \\
\hline & 05 & 09 & 06: S. warneri & O3: S. xylosus \\
\hline & 06 & 06 & 05: S. xylosus & 01: S. epidermidis \\
\hline & 07 & 05 & 05: S. sciuri & --- \\
\hline & 08 & 08 & 06: S. haemolyticus & 02: S. equorum \\
\hline & 09 & 08 & 06: S. hominis subsp. hominis & O2: S. cohnii \\
\hline & 10 & 06 & 05: S. saprophyticus & 01: S. xylosus \\
\hline \multirow{10}{*}{$\begin{array}{c}\text { Resin }=67 \\
(32.2 \%)\end{array}$} & 01 & 06 & 05: S. lentus & 01: S. sciuri \\
\hline & 02 & 06 & 05: S. epidermidis & 01: Aerococcus viridans \\
\hline & 03 & 07 & 05: S. saprophyticus & O2: S. equorum \\
\hline & 04 & 07 & 06: S. saprophyticus & 01: S. hominis subsp. hominis \\
\hline & 05 & 06 & 06: S. warneri & --- \\
\hline & 06 & 07 & 05: S. xylosus & 02: S. epidermidis \\
\hline & 07 & 05 & 05: S. sciuri & 01: S. hominis subsp. hominis \\
\hline & 08 & 09 & 07: S. haemolyticus & 02: S. equorum \\
\hline & 09 & 07 & 05: S. hominis subsp. hominis & 02: S. cohnii \\
\hline & 10 & 06 & 05: S. saprophyticus & 01: S. xylosus \\
\hline \multirow{10}{*}{$\begin{array}{c}\text { Modified } \\
\text { atmosphere }=67 \\
(32.2 \%)\end{array}$} & 01 & 09 & 06: S. lentus & 03: S. sciuri \\
\hline & 02 & 06 & 05: S. epidermidis & 01: Aerococcus viridans \\
\hline & 03 & 07 & 04: S. saprophyticus & 03: S. equorum \\
\hline & 04 & 08 & 05: S. saprophyticus & O3: S. hominis subsp. hominis \\
\hline & 05 & 05 & 05: S. warneri & --- \\
\hline & 06 & 06 & 05: S. xylosus & 01: S. epidermidis \\
\hline & 07 & 08 & 06: S. sciuri & 02: S. hominis subsp. hominis \\
\hline & 08 & 06 & O6: S. haemolyticus & --- \\
\hline & 09 & 07 & 06: S. hominis subsp. hominis & 02: S. cohnii \\
\hline & 10 & 05 & 04: S. saprophyticus & 01: S. xylosus \\
\hline
\end{tabular}

\section{PCR for detection of genes related to enterotoxins production}

A total of 14 (6.9\%) positive strains was observed in the 204 isolates coagulase-negative Staphylococcus after molecular detection, and 190 (93.1\%) were negative for enterotoxin genes (Table 3).

\section{DISCUSSION}

The pattern of bacterial species established in cheeses has been reported in several studies as very diverse, but it is correlated with the results of this study, in which similarities between isolation rates and species were presented; however, this study describes for the first time the occurrence in a different type of cheese, the Emmental cheese.

BORGES et al. (2008), studying the coalho cheese, identified three species of CNS (Staphylococcus haemolyticus, S. hyicus and $S . x y l o s u s$ ) in the raw milk as feedstock in the production process; S. cohnii, S. lentus, S. capitis and S. saprophyticus in pasteurized milk during the process; and S. epidermidis (37.5\%), S. xylosus (25.0\%), S. cohnii (6.2\%), S. haemolyticus (6.2\%) and S. lentus $(6.2 \%)$ in coalho cheese.

LAMAITA et al. (2005) isolated $31 \%$ of CNS in cooled raw milk, where they found three species, S. epidermidis, S. sciuri, and S. cohnii. In another study, CUNHA, A.; 
Table 3. Detection of enterotoxin genes from CNS isolates.

\begin{tabular}{|c|c|c|c|c|}
\hline PACKAGE & BATCHES & STRAIN & GENE & TOXIN \\
\hline \multirow{5}{*}{ ATM } & 04 & Staphylococcus saprophyticus & SEE & $\mathrm{E}$ \\
\hline & 07 & Staphylococcus hominis subsp. hominis & SEJ & $J$ \\
\hline & 08 & Staphylococcus haemolyticus & SEE & $E$ \\
\hline & 10 & Staphylococcus xylosus & SEC & C \\
\hline & 10 & Staphylococcus saprophyticus & SEE & $E$ \\
\hline \multirow{3}{*}{ RESIN } & 04 & Staphylococcus saprophyticus & SEE & $\mathrm{E}$ \\
\hline & 08 & Staphylococcus haemolyticus & SEE & $E$ \\
\hline & 10 & Staphylococcus saprophyticus & SEE & $\mathrm{E}$ \\
\hline \multirow{6}{*}{ VACUUM } & 03 & Staphylococcus equorum & SEI & 1 \\
\hline & 04 & Staphylococcus saprophyticus & SEE & $\mathrm{E}$ \\
\hline & 05 & Staphylococcus xylosus & SEE & $E$ \\
\hline & 06 & Staphylococcus xylosus & SEE & $\mathrm{E}$ \\
\hline & 08 & Staphylococcus haemolyticus & SEE & $E$ \\
\hline & 10 & Staphylococcus saprophyticus & SEE & $\mathrm{E}$ \\
\hline
\end{tabular}

CUNHA, M. (2007) evaluated isolates of Staphylococcus spp. from food, including milk and dairy products, and reported that the species of major occurrence were $S$. epidermidis (40\%), S. xylosus (20\%), S. warneri (20\%), S. saccharolyticus (15\%) and $S$. hominis (5\%).

DE LUCA et al. (1997) isolated 313 strains of Staphylococcus spp. from 135 sampled cheese of many types, and the predominant species were S. hominis (19.5\%), S. xylosus (19.2\%), S. epidermidis (14.8\%) and S. cohnii (16.3\%).

FLEMING et al.(2010) found 45 samples of cheese (2 of "bola" type, 1 of cheddar type, 1 of estepe type, 10 of "minas" type, 14 of mozzarella type, 5 of parmesan type, 11 of "prato" type and 1 of provolone type) and isolated 37 strains of the following CNS: S. lentus, S. capitis, S. caprae, S. kloosii, S. gallinarum, S. simulans and S. epidermidis.

SENA (2000) analyzed 90 samples of coalho cheese and isolated 377 strains of Staphylococcus spp., 137 strains of CNS, distributed as: 96 (25.5\%) of S. epidermidis, 41 (10.9\%) and S. hyicus. VALLE et al. (1990) isolated 342 Staphylococcus spp. of goat milk and identified different coagulase-negative species: S. chromogenes, S. warneri, S. sciuri, S. saprophyticus and S. lentus.

In the present study, a total of 204 isolates were obtained of many types of packages, distributed in 10 species of CNS, and characterized as: 46 (22.6\%) S. saprophyticus; 27 (13.2\%) S. hominis subsp. hominis; 22(10.8\%) S. sciuri; 21 (10.3\%) S. xylosus; 19 (9.3\%) S. epidermidis; 19 (9.3\%) S. haemolyticus; 17 (8.3\%) S. lentus; 17 (8.3\%) S. warneri; 11 (5.4\%) S. equorum and $5(2.5 \%) S$. cohnii. It is noteworthy that the $S$. equorum species was isolated in this study, which is not related to any of the other studies described above.

In the present study, 14 (6.9\%) staphylococcal enterotoxin (SE) were detected for CNS and 190 (93.1\%) were negative for toxins genes. LAMAITA et al. (2005) showed the presence of staphylococcal toxin in cooled raw milk samples using the optimum sensitivity plate (OSP) method, and verified that the pools of $91(41.3 \%)$ isolates from CNS produced a few kinds of toxins as: SEA, SEB, SEC, SED and the Tsst-1 toxin. In this study, the major incidence for SE was E type (SEE) in $11(78.6 \%)$ of 14 strains, which highlights the novel results, because the toxin $\mathrm{E}$ was detected in samples of Emmental cheese for the first time.

STAMFORD et al. (2006) studied samples of raw milk from Pernambuco public market, of which 109 strains of Staphylococcus spp. were isolated, and 32 of them were characterized as CNS using biochemical tests, but their results cannot be entirely compared with the results presented in this study because the 5 strains that tested positive for toxin production did not have the confirmation of toxin type. Although CNS species are not usually considered an object of epidemiological importance for Staphylococcus intoxication, it was previously stated that coagulase-negative species may be involved in outbreaks (PEREIRA et al., 2001). Likewise, OLIVEIRA (1999) evaluated samples in powdered milk and cooked ham, obtaining 10 strains of CNS with enterotoxigenic potential belonging to the species: S. epidermitis, S. chromogenes, S. hominis, S. hyicus, S. warneri and $S$. xylosus, from which $S$. chromogenes and S. Warneri produced enterotoxin in food.

This study describes that all the Staphylococcus spp. were characterized as CNS with the potential of enterotoxin production, mainly for the E, I and J types. The type of package did not inhibit bacterial growth, because in all the packages tested (resin, vacuum and modified atmosphere) there was growth of Staphylococcus spp.

Even though the counting for Staphylococcus spp. were within the permitted limits for cheese in this study, further 
investigation is needed to relate the cases of microorganisms involved as the enterotoxigenic Staphylococcus group in food, and correlate the production of coagulase enzymes with capacity of enterotoxigenic production. This statement is corroborated by SU; WONG (1997), who observed that the capacity of coagulase production cannot be designed as a unique indication of enterotoxicity. Therefore, CNS must be considered as an object of importance in the epidemiology of Staphylococcus food intoxication and an alert to health authorities on the risk of the presence of microorganisms.

ACKNOWLEDGEMENTS: Not applicable.

FUNDING: This study was financed in part by the Coordenação de Aperfeiçoamento de Pessoal de Nível Superior - Brasil (CAPES) - Finance Code 001.

CONFLICTS OF INTEREST: All authors declare that they have no conflict of interest.

ETHICAL APPROVAL: Not applicable.

AVAILABILITY OF DATA AND MATERIAL: All data generated or analyzed during this study are included in this published article.

AUTHORS' CONTRIBUTIONS: Conceptualization: Nascimento, A.L.; Rezende, A.A.R.; Pinheiro, E.S.; Nassar, A.F.C. Data curation: Nascimento, A.L.; Sousa, R.S.; De Mattos, E.C; Dal Col, R. Formal analysis: Nascimento, A.L.; Pinheiro, E.S.; Daros, V.S.M.; Rezende, A. A. R.; Nassar, A.F.C. Methodology: Nassar, A.F.C.; Pinheiro, E.S.; Sousa, R.S.; Nascimento, A.L. Writing review \& editing: Nassar, A.F.C.; Pinheiro, E.S.; Nascimento, A.L.

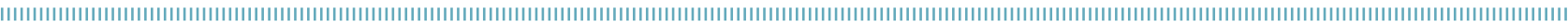
REFERENCES

BORGES, M.F.; ARCURI, E.F.; PEREIRA, J.L.; FEITOSA, T.; KUAYE, A.Y. Staphylococcus enterotoxigênicos em leite e produtos lácteos, sua enterotoxinas e genes associados: Revisão. Boletim do Centro de Pesquisa de Processamento de Alimentos, Curitiba, v.26, n.1, p.71-86, 2008. https://doi.org/10.5380/ cep.v26i1.11794

BRAZIL. Ministério da Agricultura, Pecuária e Abastecimento. Portaria n 146, de 07 de março de 1996. Anexo I - Regulamento técnico de identidade e qualidade de queijos. 1996. Available from: https://www.defesa.agricultura.sp.gov.br/legislacoes/ portaria-mapa-146-de-07-03-1996,669.html. Access on: 11 Nov. 2013.

BRAZIL. Agência Nacional de Vigilância Sanitária. Resolução $n^{\circ} 12$, de 2 de janeiro de 2001. Regulamento técnico sobre os padrões microbiológicos para alimentos. 2001. Available from: http://portal. anvisa.gov.br/documents/33880/2568070/RDC_12_2001. pdf/15ffddf6-3767-4527-bfac-740a0400829b. Access on: 8 Nov. 2013.

BRAZIL. Ministério da Agricultura, Pecuária e Abastecimento. Instrução Normativa SDA - 62, de 26 de agosto de 2003. Anexo IV - Procedimentos para contagem de colônias. 2003a. Available from: https://www.defesa.agricultura.sp.gov.br/legislacoes/ instrucao-normativa-sda-62-de-26-08-2003,665.html. Access on: 11 Nov. 2013.
BRAZIL. Ministério da Agricultura, Pecuária e Abastecimento. Instrução Normativa SDA- 62, de 26 de agosto de 2003. Anexo I - Capítulo V. 2003b. Available from: https://www.defesa. agricultura.sp.gov.br/legislacoes/instrucao-normativa-sda62-de-26-08-2003,665.html. Access on: 11 Nov. 2013.

CARDOSO, H.F.T. Identificação de fatores de virulência e susceptibilidade a antimicrobianos de Staphylococcus aureus isolados de amostras de leites bovino em Minas Gerais. 1999. Dissertation (Master in Preventive Veterinary Medicine) Universidade Federal de Minas Gerais, Belo Horizonte, 1999.

CARMO, L.S. et al. Food poisoning due to enterotoxigenic strains of Staphylococcus present in Minas cheese and raw milk in Brazil. Food Microbiology, Vigo, v.19, n.1, p.9-14, 2002. https://doi. org/10.1006/fmic.2001.0444

CHANG, M.R.; CARVALHO, N.C.P.; OLIVEIRA, A.L.L.; MONCADA, P.M.F.; MORAES, B.A.; ASENSI, M.D. Surveillance of pediatric infections in a teaching hospital in Mato Grosso do Sul, Brazil. Brazilian Journal of Infectious Diseases, Salvador, v.7, n.2, p.149-160, 2003. https://doi.org/10.1590/S1413-86702003000200009

CUNHA, M.L.R.S.; LOPES,C.A.M.; RUGOLO, L.M.S.S.; CHALITA, L.V.A.S. Clinical significance of coagulase-negative staphylococci isolated from neonates. Jornal de Pediatria, Rio de Janeiro, v.78, n.4, p.279-288, 2002. https://doi.org/10.2223/JPED.861 
CUNHA, A.S.; CUNHA, M.R. Toxinfecção alimentar por Staphylococcus aureus através do leite e seus derivados, bem como o elevado potencial patogênico de resistência às drogas. Saúde e Ambiente em Revista, Rio de Janeiro, v.2, n. 1, p.105-114, 2007.

DE LUCA, G.; ZANETTI, F.; STAMPI, S. Staphylococcus aureus in dairy products in the Bologna area. International Journal of Food Microbiology, Torino, v.35, n.3, p.267-270, 1997. https://doi. org/10.1016/SO168-1605(96)01229-9

FLEMING, L.R.; BOLZAN, D.N.; BANDEIRA, S.O.; NASCIMENTO, J.S. Quantificação e resistência a antibióticos de Staphylococcus isolados de queijos. Perspectivas da Ciência e Tecnologia, Rio de Janeiro, v.2, n. 1-2, p.13-19, 2010.

GERMANO, P.M.L.; MIGUEL, M.; MIGUEL, O.; GERMANO, M.I.S. Prevenção e controle das toxinfecções de origem alimentar. Higiene Alimentar, São Paulo, v.7, n.27, p.6-11, 1993.

JAY, J.M. Staphylococcal gastroenteritis. In: Modern Food Microbiology. Gaithersburg Aspen Publishers, Inc., 2000. 441p. Chap. 23.

KLOOS, W.E.; BANNERMAN, T.L. Update on clinical significance of coagulase-negative staphylococci. Clinical Microbiology Reviews, Washington, v.7, n.1, p.117-140, 1994. https://doi. org/10.1128/CMR.7.1.117-140.1994

LAMAITA, H.C.; CERQUEIRA, M.M.O.P; CARMO, L.S.; SANTOS, D.A.; PENNA, C.F.A.M.; SOUZA, M.R. Contagem de Staphylococcus sp. e detecção de enterotoxinas estafilocócicas e toxina da síndrome do choque tóxico em amostras de leite cru refrigerado. Arquivo Brasileiro Medicina Veterinária eZootecnia, Belo Horizonte, v.57, n.5, p.702-709, 2005. https://doi.org/10.1590/S0102-09352005000500017

LøVSETH, A., LONCAREVIC, S.; BERDAL, K.G. Modified multiplex PCR method for detection of pyrogenic exotoxin genes in staphylococcal isolates. Journal Clinical Microbiology, Washington, v.42, n.8, p.38693872, 2004. https://doi.org/10.1 128/JCM.42.8.3869-3872.2004

OLIVEIRA, A.M. Investigação do comportamento de estafilococos esterotoxigênicos coagulase negativos, em alimentos. 1999. Thesis (Doctorate in Food Science) - Universidade Estadual de Campinas, Campinas, 1999. Available from: http://repositorio.unicamp.br/ bitstream/REPOSIP/254579/1/Oliveira_AnaMariade_D.pdf. Access on: 27 Jul. 2016.

OMOE, K.; HU, D.-L.; TAKAHASHI-OMOE, H.; NAKANE, A.; SHINAGAWA, $K$. Comprehensive analysis of classical and newly described staphylococcal superantigenic toxin genes in Staphylococcus aureus isolates. FEMS Microbiology Letters, Delft, v.246, n.2, p. 191-198, 2005. https://doi.org/10.1016/j.femsle.2005.04.007
PEREIRA, M.L., CARMO, L.S., PEREIRA, J.L. Comportamento de estafilococos coagulase negativos produtores de enterotoxinas em alimentos experimentalmente inoculados. Food Science and Technology, Campinas, v..21, n.2, p.171-175, 2001.https://doi. org/10.1590/SO101-20612001000200009

PIMENTEL, F.E.; DIAS, R.S.; CARMO, L.S. Presença de Staphylococcus sp. enterotoxigênicos e de enterotoxinas em queijo ralado. Revista do Instituto Laticínios, Cândido Tostes, Juiz de Fora, v.57, p.227-229, 2002.

REDAÇÃO DCI DIGITAL. Produção de queijo deve crescer 2,5\% neste ano com aumento do consumo. 2018. Available from: https://www.dci.com.br/industria/produc-o-de-queijo-devecrescer-2-5-neste-ano-com-aumento-do-consumo-1.698571. Access on: 30 Apr. 2019.

SOUZA, L.M.A. Carta leite - queijos: preços e consumo em tempos de COVID-19. SCOT CONSULTORIA. 2020. Available from: https:// www.scotconsultoria.com.br/imprimir/noticias/52622. Access on: 23 Sep. 2020.

SENA, M.J. Perfil epidemiológico, resistência a antibióticos e aos conservantes Nisina e sistema lactoperoxidase de Staphylococcus sp isolados de queijos coalho comercializados em Recife - PE. 2000. Thesis (Doctorate in Animal Science) - Universidade Federal de Minas Gerais, Belo Horizonte, 2000. Available from: https:// repositorio.ufmg.br/handle/1843/BUOS-8FUK7Y. Access on: 27 Jul. 2016

SIEGEL; CASTELLAN JUNIOR, N.J. Estatística não-paramétrica para ciências do comportamento. 2 ed. São Paulo: Varela, 2006. 295p.

STAMFORD, T.L.M.; SILVA, C.G.M.; MOTA, R.A.; CUNHA NETO, A.C. Enterotoxigenicidade de Staphylococcus spp. isolados de leite in natura. Food Science and Technology, Campinas, v.26, n.1, p.41-45, 2006. https://doi.org/10.1590/ So101-20612006000100007

SU, Y.-C.; WONG, A.C.L. Current perspectives on detection of staphylococcal enterotoxins. Journal of Food Protection, Des Moines, v.60, n.2, p.195-201, 1997. https://doi. org/10.4315/0362-028X-60.2.195

VALLE, J.; GOMEZ-LUCIA, E.; PIRIZ, S.; GOYACHE, J.; ORDEN, J.A.; VADILLO, S. Enterotoxin production by staphylococci isolated from healthy goats. Applied and Environmental Microbiology, Washington, v.56, n.5, p.1323-1326, 1990.https://doi.org/10.1128/ AEM.56.5.1323-1326.1990 